\title{
PENGARUH ROE, DAR, DER, EAR TERHADAP ROA DENGAN NPM DAN CSR SEBAGAI VARIABEL INTERVENING
}

\author{
M. Mustaqim \\ Pondok Pesantren Ainul Yaqin Universitas Islam Malang \\ Email :Takimalkat62@gmail.com
}

\begin{abstract}
Abstrak
Tujuan penelitian ini adalah menjelaskan kembali teori tentang Pengaruh $R O E, D A R, D E R$, EAR terhadap ROA dengan NPM dan CSR sebagai variabel intervening (Studi Empiris Pada Perusahaan Manufaktur Yang Terdaftar di BEI tahun 2015-2017). Dengan menggunakan variabel bebas $R O E, D A R, D E R, E A R$ dan Variabel terikat ROA serta Variabel NPM dan CSR sebagai variabel intervening Populasi penelitian ini adalah perusahaan Manufaktur yang terdaftar di BEI. Sampel pada penelitian ini sejumlah 49 perusahaan Manufaktur dalam periode 2051-2017 yang memiliki laporan keuangan secara berturut-turut dan dipublikasikan. Jenis penelitian ini adalah explanative reseach. Metode penelitian yang digunakan menggunakan Path Analysis untuk mengetahui besarnya pengaruh variabel independen terhadap variabel dependen.

Hasil penelitian menunjukkan ROE, DAR, DER dan NPM berpengaruh secara langsung terhadap $R O A$. Sedangkan $E A R$ dan CSR secara langsung tidak berpengaruh terhadap $R O A$. Hasil pengujian $R O E$ secara langsung berpengaruh terhadap NPM. Sedangkan DAR, DER dan EAR secara langsung tidak berpengaruh terhadap NPM. Hasil pengujian ROE dan DAR secara langsung berpengaruh terhadap $C S R$, sedangkan $D E R$ dan $E A R$ secara langsung tidak berpengaruh terhadap CSR. Hasil pengujian koefisien dari analisis jalur secara tidak langsung menunjukan bahwa ROE berpengaruh terhadap ROA melalui NPM sedangkan $D A R, D E R$ dan EAR tidak berpengaruh terhadap $R O A$ melalui NPM. Dan dari Hasil pengujian koefisien dari analisis jalur secara tidak langsung menunjukan bahwa $R O A, D A R, D E R$ dan EAR tidak berpengaruh terhadap $R O A$ melalui $C S R$.
\end{abstract}

Kata kunci: $R O E, R O A, N P M, D A R, D E R, E A R$, dan CSR.

\section{Abstract}

The purpose of this research to re-explain the theory of the influence on ROE, DAR, DER, EAR abaout ROA with NPM and CSR as intervening variable. $B y$ using the independent variable ROE, DAR, DER, EAR, the dependent variable $R O A, N P M$ and CSR as intervening variable. The research population is manufacture companies that listed at BEl. The number of The sample In this research is 49 companies manufacture in 2015-2017 who have complete financial reports respectively and published. This research type is an explanative research and using method by path analysis to find out the magnitude of the effect of independent variables on the dependent variable.

The results of this reset showed ROE, DAR, DER and NPM direct impact on ROA. Whereas EAR and CSR do not have directly effect on ROA. The ROE test results directly effect on NPM. Whereas DAR, DER and EAR directly do not have effect on NPM. ROE and DAR test results directly effect on CSR, while DER and EAR directly do not have effect on CSR. The coefficient test results from the path analysis indirectly show that ROE influence on ROA through NPM while DAR, $D E R$ and EAR have no effect on ROA through NPM. And the coefficient test results from the path analysis indirectly show that ROA, DAR, DER and EAR have no effect on ROA through CSR. 
Keywords: ROE, ROA,NPM,DAR, DER, EAR, and CSR.

\section{PENDAHULUAN \\ Latar Belakang Masalah}

Tujuan utama perusahaan didirikan adalah untuk meningkatkan dan mensejahterakan pemegang sahamnya. Kesejahteraan dapat ditingkatkan melalui kinerja perusahaan, kinerja perusahaan yang baik dapat dilihat dari kinerja keuangan perusahaan. Kinerja keuangan perusahaan merupakan kemampuan atau prestasi perusahaan dalam menjalankan usahanya secara finansial ditunjukan dalam laporan keuangan (Syari, 2014).

Kinerja keuangan perusahaan dapat dilihat dari adanya peningkatan pendapatan yang mempengaruhi laba. Kinerja perusahaan diukur dengan menggunakan rasio Profitabilitas. Rasio Profitabilitas dihitung menggunakan ukuran ringkasan utama dari laporan laba rugi (laba dan penjualan) dan neraca (aset dan ekuitas). Ukuran profitabilitas diantaranya adalah Return on Equity ( ROE ), Net Profit Margin ( NPM ) dan Return On Asset ( ROA ).

Perusahaan dalam menjaga kelangsungan hidup jangka panjang harus menghasilkan laba. Laba perusahaan yang tinggi akan meningkatkan kesejahteraan bagi para pemilik saham. Di sisi lain, laba perusahaan yang tinggi juga akan meningkatkan pertumbuhan usaha perusahaan karena meningkatnya atau besarnya salah satu sumber modal juga tergantung pada besarnya laba yang akan dicapai perusahaan.

Upaya mengatasi pengaruh laba, manajer keuangan harus ber-hatihati dalam menetapkan Debt to Asset Ratio ( DAR ), Debt to Equity Ratio ( DER ) dan Equity to Asset Ratio (EAR) yang termasuk dalam pengukuran Struktur Modal. Karena Struktur Modal yang diharapkan perusahaan dapat meningkatkan Return On Asset (ROA) perusahaan. Persaingan bisnis yang semakin kompetitif menjadikan tugas manajer keuangan semakin berat yaitu mencari alternatif pendanaan yang dapat meminimkan biaya modal. Oleh karena itu yang harus dipertimbangkan perusahaan adalah keputusan menentukan struktur modal. Struktur modal merupakan perimbangan antara modal asing atau hutang dengan modal sendiri (Sutrisno 2001). Struktur modal yang sering dipakai dalam penelitian antara lain Debt to total Asset Ratio, Debt to Equity Ratio, Equity to Asset Ratio, Long Term Debt to Equity Ratio, dan Long Term Debt to Total Asset Ratio.

Selain berhati-hati dalam menentukan Struktur Modal manajer keuangan juga diharap mampum meningkatkan perhatian investor dengan melakukan pengungkapan CSR sehingga dapat meningkatkan citra positif perusahaan dimasyarakat maupun investor. Investor lebih berminat pada perusahaan yang memiliki citra yang baik di masyarakat, karena semakin baik citra perusahaan, maka loyalitas konsumen semakin tinggi sehingga dalam jangka waktu tertentu profitabilitas perusahaan membaik (Reny dan Retno 2012).

Perusahaan dalam aktivitasnya tidak hanya bertanggung jawab kepada perusahaan itu sendiri yaitu dengan meningkatkan laba setinggitingginya akan tetapi juga memiliki tanggung jawab terhadap semua stakeholder, termasuk didalamnya adalah pelanggan atau customer, 
pegawai, komunitas, pemilik atau investor, pemerintah, supplie bahkan juga kompetitor. Ini sesuai dengan apa yang menjadi aturan dalam setiap pendirian perusahaan yang sesuai dengan ISO 26000, UU no. 40 tahun 2007 serta peraturan BAPEPAM dan Lembaga Keuangan Nomor: Kep431/Bl/2012 yang menyempurnakan Peraturan Bapepam Nomor X.K.6.

Dalam kebijakan struktur modal melibatkan risiko dan tingkat pengembalian yang diharapkan semakin tinggi, ini berdampak pada hutang yang semakin tinggi, akan tetapi tingkat pengembalian diharapkan akan semakin tinggi pula. Dengan demikian laba yang dihapakan perusahaan akan semakin meningkat. Dan untuk melaksanakan CSR berarti perusahaan akan mengeluarkan sejumlah biaya. Biaya tersebut akan menjadi beban baru perusahaan yang pada akhirnya mengurangi pendapatan perusahaan sehingga laba perusahaan akan turun. Akan tetapi dengan melaksanakan CSR, citra perusahaan akan semakin baik., kepercayan konsumen meningkat sehingga meningkatkan loyalitas konsumen, seiring dengan meningkatnya kepercayaan dan loyalitas konsumen, makapenjualan akan semakin meningkat dan pada akhirnya dengan melaksanakan CSR diharap dapat meningkatkan profitabilitas ( ROA ) perusahaan. Return On Asses (ROA) yang positif menunjukan bahwa dari total aktiva yang dipergunakan untuk operasi perusahaan mampu memberikan laba bagi perusahaan. Sebaliknya jika Return On Asses (ROA) negatif menunjukan total aktiva yang di pergunakan tidak memberikan keuntungan atau rugi.

Adapun tujuan penelitian ini adalah sebagai berikut, 1) Untuk menganalisis pengaruh $R O E, D A R, D E R, E A R$, terhadap $R O A$. 2) Untuk menganalisis pengaruh $R O E, D A R, D E R, E A R$, terhadap NPM. 3) Untuk menganalisis pengaruh $R O E, D A R, D E R, E A R$, terhadap CSR. 4) Untuk menganalisis pengaruh NPM dan CSR terhadap ROA.

\section{KAJIAN TEORI \\ Kinerja Keuangan}

Kinerja perusahaan dapat dikatakan sebagai suatu usaha formal yang dilaksanakan perusahaan untuk mengevaluasi efisien dan efektivitas dari aktivitas perusahaan yang telah dilaksanakan pada periode waktu tertentu. Menurut Sucipto (2003:6) pengertian kinerja keuangan adalah "penentuan ukuran-ukuran tertentu yang dapat mengukur keberhasilan suatu organisasi atau perusahaan dalam menghasilkan laba".

Adapun rasio kinerja keuangan dikelompokkan kedalam rasio-rasio likuiditas, rasio-rasio leverage, rasio-rasio aktivitas, dan rasio-rasio profitabilitas (Riyanto, 2001):

a. Rasio Likuiditas adalah rasio-rasio yang dimaksudkan untuk mengukur likuiditas perusahaan (current ratio, acid test ratio).

b. Rasio Leverage Adalah rasio-rasio yang dimaksudkan untuk mengukur sampai berapa jauh aktiva perusahaan dibiayai oleh utang. (debt to total assets ratio, net worth to debt ratio dan lain sebagainya)

c. Rasio-rasio Aktivitas yaitu rasio-rasio yang dimaksudkan untuk mengukur sampai seberapa besar efektivitas perusahaan dalam 
mengerjakan sumber- sumber dayanya (inventory turnover, average collection period, dan lain sebagainya).

d. Rasio-rasio Profitabilitas yaitu rasio-rasio yang menunjukkan hasil akhir dari sejumlah kebijaksanaan dan keputusan-keputusan (profit margin. Return on assets, Return On Equity, Net Profit Margin dan lain sebagainya.

e. Rasio-rasio penilaian yaitu rasio-rasio untuk mengukur kemampuan perusahaan dalam menciptakan nilai pada investor atau pada para pemegang saham (Price Earning Ratio dan Market to book Value).

Dalam tugas akhir ini rasio-rasio yang digunkan adalah Return on assets (ROA) sebagai variabel dependen Return On Equity sebagai variabel independen (ROE), Net profit margin (NPM) sebagai variabel intervening.

\section{Return on Aset (ROA) sebagai Variabel Dependen}

Return on Aset adalah perbandingan antara laba bersih setelah pajak dengan aktiva untuk mengukur tingkat pengembalian investasi total. Rasio ini merupakan rasio yang terpenting untuk mengetahui profitabilitas suatu perusahaan. Return on Asset merupakan ukuran efektifitas perusahaan di dalam menghasilkan keuntungan dengan memanfaatkan aktiva yang dimilikinya.

$$
R O A=\frac{E A T}{\text { Total Asset }} \times 100 \%
$$

\section{Return On Equity (ROE) sebagai variabel Independen}

Return on Equity ini sering disebut dengan rate of return on Net Worth yaitu kemampuan perusahaan dalam menghasilkan keuntungan dengan modal sendiri yang dimiliki, sehingga ROE ini ada yang menyebutnya sebagai rentabilitas modal sendiri. Laba yang diperhitngkan adalah laba bersih setelah dipotong pajak atau EAT. Dengan demikian rumus yang digunakan adalah:

$$
R O E=\frac{E A T}{\text { Modal Sendiri }} \times 100 \%
$$

\section{Net Profit Margin (NPM) sebagai variabel intervening}

Net Profit Margin adalah membandingkan antara laba setelah bunga dan pajak dibandingkan dengan penjualan. Rasio ini menunjukkan pendapatan bersih perusahaan atas penjualan. Rumus yang bisa digunakan adalah:

\section{Struktur Modal}

$$
\mathrm{NPM}=\frac{E A T}{\text { Penjualan }} \times 100 \%
$$

Menurut (Sutrisno 2007) Struktur modal merupakan imbangan antara modal asing atau hutang dengan modal sendiri. Struktur modal merupakan kombinasi antara berbagai komponen pada sisi kanan neraca yaitu, utang dan ekuitas. Saat memperoleh modal perusahaan akan menggunakannya sebagai operasional perusahaan dan menginvestasikannya. Sehingga perusahaan menghasilkan keuntungan lebih dari modal yang telah digunakan untuk berbagai kegiatan perusahaan. Oleh sebab itu manajer keuangan harus menyeimbangkan sumber pendanaan untuk memperoleh struktur modal yang optimal dengan memaksimalkan keuntungan perusahaan. 


\section{Teori Struktur Modal}

\section{Teori Tred Off Dan Teori Packing Order}

Teori tred Off dan teori packing Order merupakan teori yang menjelaskan hubungan antara pilihan struktur modal dan kinerja keuangan. Kedua teori tersebut memili asusmsi masing-masing sehingga mengakibatkan pertentangan hasil dalam suatu penelitian mengenai pengaruh struktur modal terhadap kinerja keuangan.

a. Teori Tred Off

Teori trade-off menjelaskan bahwa perusahaan menentukan tingkat utang yang optimal dengan mempertimbangkan biaya dan manfaat dari pendanaan utang (Fama dan French, 2002). Analisis trade-off ini diawali dengan asumsi pendanaan hanya dengan ekuitas, kemudian dilakukan pengamatan terhadap perubahan nilai seiring tergantikannya ekuitas dengan utang secara progresif. Penggunaan utang sebagai sumber pendanaan memiliki manfaat dalam meningkatkan nilai perusahaan hingga titik tertentu (Basyaib, 2007).

Trade-off menggambarkan suatu pengorbanan yang harus dilakukan untuk mendapatkan suatu hal yang lain. Pengorbanan di sini berarti kehilangan arus kas untuk membayar biaya yang timbul dari pendanaan utang. Sebaliknya, hal yang didapatkan atau yang ditukar dengan pengorbanan tersebut adalah manfaat dari pendanaan utang.

b. Teori Pecking Order

Teori pecking order menyatakan bahwa perusahaan memiliki tingkatan prioritas sumber pendanaan. Pertama, perusahaan akan lebih memilih untuk mendanai investasinya dengan laba ditahan. Apabila laba ditahan tidak mencukupi, barulah perusahaan akan melakukan pendanaan dari utang sebagai prioritas kedua dan penerbitan saham sebagai prioritas terakhir (Myers, 1984).

Laba ditahan menjadi pilihan pertama perusahaan karena pendanaan ini dianggap paling tidak berisiko dibandingkan utang atau penerbitan saham. Pendanaan dengan laba ditahan tidak menimbulkan kewajiban bagi perusahaan untuk membayar beban bunga atau membayar dividen. Dengan demikian, keuntungan perusahaan dapat dinikmati secara utuh oleh pemilik perusahaan.

\section{Pendekatan Tradisional}

Husnan dan Pudjiastuti (2015), Mereka yang menganut pendekatan tradisional mengatakan bahwa dalam pasar modal yang sempurna dan tidak ada pajak, nilai perusahaan bisa dirubah dengan cara merubag struktur modalnya.

\section{Pendekatan modigliani dan Miller}

Husnan dan Pudjiastuti (2015), Dalam artiker mereka, dua orang ekonom Modigliani dan miller (yang biasanya disebut dengan MM) menunjukkan bahwa pendapat pendekatan tradisional adalah tidak benar. Mereka menunjukkan kemungkinan munculnya arbitrage yang akan membuat harga saham yang tidak menggunakan hutang maupun yang menggunakan hutang, akhirnya sama. Proses arbitrage muncul karena investor selalu lebih menyukai investasi yang memerlukan dana yang lebih 
sedikit tetapi memberikan penghasilan bersih yang sama dengan resiko yang sama pula.

Dalam tugas aikhir ini peneliti menggunakan bagian dari struktur moadal antara lain: Debt to Asset Ratio, Debt to Equity Ratio, Eaquity to Asset Ratio sabagai Variabel Independen.

\section{Debt to total Asset Ratio (DAR)}

Debt to total Asset Ratio (DAR) adalah sebuah rasio untuk mengukur jumlah aset yang dibiayai oleh hutang. Rasio ini juga sangat penting untuk melihat solvabilitas perusahaan. Solvabilitas adalah kemampuan perusahaan untuk menyelesaikan segala kewajiban jangka panjangnya. Rumus yang digunakan sebagai beriku;

$$
D A R=\frac{\text { Total Hutang }}{\text { Total Aset }} \times 100 \%
$$

\section{Debt to Equity Ratio (DER)}

Debt to Equity Ratio (DER) adalah suatu rasio keuangan yang menunjukan proporsi relatif antara Ekuitas dan Hutang yang digunakan untuk membiayai aset perusahaan dan digunakan untuk mengukur seberapa baik struktur investasi suatu perusahaan. Rumus yang digunakan sebagai beriku;

$$
D E R=\frac{\text { Total Hutang }}{\text { Ekuitas }} \times 100 \%
$$

\section{Equity to Asset Ratio (EAR)}

Equity to Asset Ratio (EAR) adalah merupakan variabel yang didefinisikan sabagai proporsi dana dari aktiva yang sumber pendanaannya berasal dari ekuitas atau pemegang saham. Rumus yang digunakan sebagai berikut;

$$
E A R=\frac{\text { Total Ekuitas }}{\text { Total Aset }} \times 100 \%
$$

\section{Corporate Social Responsibility (CSR)}

Menurut undang-undang perseroan terbatas No. 40 tahun 2007 pasal 1 ayat 3. Tanggung jawab sosial dan lingkungan adalah komitmen perseroan untuk berperan serta dalam pembangunan ekonomi berkelanjutan guna meningkatkan kualitas kehidupan dan lingkungan yang bermanfaat baik perseroan sendiri, komunitas setempat maupun masyarakat pada umumnya.

Komitmen perusahaan merupakan tanggung jawab moral perusahaan atas komunitas sekitas perusahaan untuk membentuk kepercayaan komunitas tersebut untuk meningkatkan profitabilitas perusahaan.

\section{Teori Stakeholder (Stakeholder Theory)}

Stakeholder adalah semua pihak baik eksternal maupun internal yang memiliki hubungan baik bersifat mempengaruhi maupun dipengaruhi, bersifat langsung maupun tidak langsung oleh perusahaan (Hadi, 2011). Menurut Budimanta dkk (2008), stakeholder adalah sebagian anggota komuniti, atau kelompok individu, masyarakat yang berasal dari wilayah 
korporat tersebut berdiri, wilayah Negara dan juga Negara lain yang mempunyai pengaruh terhadap jalannya suatu korporat.

Teori stakeholder adalah teori yang menggambarkan kepada pihak mana saja perusahaan bertanggung jawab (Freeman, 2001). Oleh karena itu perusahaan harus menjaga hubungan baik dengan stakeholder terutama stake holder yang memiliki power, jika mampu menjaga hubungan tersebut maka perusahaan akan mendapat dukungan secara berkesinambungan dan dapat menikmati pertumbuhannya. Stakeholder dianggap penting dan berpengaruh bagi perusahaan karena berjalan tidaknya perusahaan ada pada stakeholdernya.

\section{Teori Legitimasi}

Teori legitimasi menyatakan bahwa organisasi harus secara terus menerus mencoba untuk meyakinkan bahwa mereka melakukan kegiatan sesuai dengan batasan dan norma-norma masyarakat. Legitimasi dianggap sebagai asumsi bahwa tindakan yang dilakukan suatu entitas merupakan tindakan yang diinginkan, pantas atau sesuai dengan sistem, norma nilai kepercayaan dan definisi yang dikembangkan secara sosial. (Rustiarini, 2011).

Legitimasi merupakan faktor strategis bagi perusahaan dalam rangka membangun perusahaan. Haltersebut dapat dijadikan wahan untuk mengontruksi strategi perusahaan, terutama terkait dengan upaya memposisikan diri ditengah lingkungan masyarakat yang semakin maju. Legitimasi merupakan keadaan psikologis keberpihakan orang dan kelompok yang sangat peka terhadap gejala lingkungan sekitar baik fisik maupun non fisik (Hadi, 2011).

Dasar pemikiran teori ini adalah organisasi atau perusahaan akan terus berlanjut keberadaannya jika masyarakat menyadari bahwa organisasi beroperasi untuk sistem nilai yang sepadan dengan sistem nilai masyarakat itu sendiri. Teori legitimasi menganjurkan perusahaan untuk meyakinkan bahwa aktivitas dan kinerjanya dapat diterima oleh masyarakat. Perusahaan menggunakan laporan tahunan mereka untuk menggambarkan kesan tanggung jawab lingkungan, sehingga mereka diterima oleh masyarakat.

Dalam pengungkapan CSR digunakan indikator menurut Sembiring (2005). Yang dihitung menggunakan rumus:

Keterangan :

$$
\operatorname{CSRD}=\frac{\mathrm{V}}{\mathrm{M}}
$$

CSRD: indeks CSR disclosure perusahaan

$\mathrm{V} \quad$ : jumlah item yang sesungguhnya diungkap perusahaan

M : jumlah item yang diharapkan diungkap perusahaan

\section{METODE PENELITIAN}

Jenis Penelitian ini menggunakan Explanatory Reseach dengan menggunakan data sekunder yang diperoleh dari BEI melalui www.idx.co.id. dan yang di publis dari website perusahaan. data tersebut digunakan untuk mengalisis hubungna kausalitas antara variabel independen pada variabel dependen. data yang yang diambil dari data-data 
laporan keuangan perusahaan manufaktur yang terdaftar di BEI tahun 2015-2017.

Metode analisis yang digunakan adalah Path Analysis dengan menggunakan Amos. Yaitu pemodelan yang mengalisis hubungan kausalita antara seperangkat variabel independen pada variabel dependen dimana secara konseptual ada hubungan kausalitas diantara variabel independen yang satu dengan variabel bebas lainnya.

Populasi dalam penelitian ini adalah perusahaan manufaktur yang listed di BEI merupakan industri dasar dan kimia, aneka industri dan industri barang konsumsi. Jumlah populasi dalam penelitian ini perusahan manufaktur yang terdaftar di BEI sebanyak 144 perusahaan.

Teknik pengambilan sampel dalam penelitian ini adalah purposive sampling dengan kriteria: (1) perusahaan yang terdaftar di BEI (2) perusahaan manufaktur tahun 2015-2017. (3) perusahaan yang mengeluarkan atau mempablikasikan laporan keuangan tahunan tiga tahun berturut-turut (4) perusahaan yang melakukan pengungkapan CSR. Sampel penelitian ini sebanyak 49 Perusahaan untuk tiga tahun periode 2015-2017 terpilih sebagai sample penelitian.

Metode analisis data menggungakan Path Analysis dengan persamaan struktural sebagai berikut:

1. $R O A=\beta_{1} R O E+\beta_{2} D A R+\beta_{3} D E R+\beta_{4} E A R+e_{3}$

2. $R O A=\beta_{5} N P M+\beta_{6} C S R+e_{3}$

3. $\mathrm{NPM}=\beta_{1} \mathrm{ROE}+\beta_{2} \mathrm{DAR}+\beta_{3} \mathrm{DER}+\beta_{4} \mathrm{EAR}+\mathrm{e}_{1}$

4. $\mathrm{CSR}=\beta_{1} \mathrm{ROE}+\beta_{2} \mathrm{DAR}+\beta_{3} \mathrm{DER}+\beta_{4} \mathrm{EAR}+\mathrm{e}_{2}$

\section{PEMBAHASAN}

\section{Evaluasi Normalitas}

Deteksi terhadap normalitas data digunakan nilai Critical Ratio (CR) Skewness dan /atau kurtosis dengan cut-off 2,58 yang dapat dilihat pada Assesment Of Normality. Keputusan hasil uji normalitas adalah Bilamana I CR-stat I $<2.58$ data berdistribusi normal Bilamana I CR-stat I $\geq 2.58$ data tidak berdistribusi normal

Tabel 4.1 Assessment of Normality (Group number 1)

\begin{tabular}{|l|l|l|l|l|l|l|}
\hline Variable & min & max & skew & c.r. & kurtosis & c.r. \\
\hline EAR &, 262 &, 907 &, 089 &, 359 &,- 946 & $-1,911$ \\
\hline DAR &, 095 &, 738 &,- 085 &,- 342 &,- 923 & $-1,865$ \\
\hline ROE &,- 221 &, 373 &, 131 &, 529 &, 136 &, 274 \\
\hline DER &, 105 & 2,821 & 1,026 & 4,146 &, 553 & 1,118 \\
\hline CSR &, 300 &, 800 &,- 302 & $-1,222$ &,- 978 & $-1,975$ \\
\hline NPM &,- 100 &, 475 & 1,090 & 4,404 & 2,984 & 6,030 \\
\hline ROA &,- 155 &, 300 &, 908 & 3,670 & 1,966 & 3,974 \\
\hline Multivariate & & & & & 29,373 & 12,952 \\
\hline
\end{tabular}

Tabel diatas mengindiskasikan bahwa hasil analisis secara multivariat data tidak berdistribusi nomal yang ditunjukan oleh I CR-stat I $=12,952 \geq 2.58$. namun hal ini dapat diselesaikan dengan cara menggunakan teknik Bootstrap, yaitu program yang disediakan oleh AMOS untuk mengatasi 
problem penyimpangan asumsi multivariate normality yang di perkenalkan dan dikembangakan oleh Elfron $(1979,1982)$.

Dengan melakukan uji Bsotstrap maka menghasilkan nilai Goodness

Of Fit sebagai berikut;

Chi-square $=0,086$

DF $\quad=1$

Probability $=0,769$

GFI $\quad=1,000$

$\mathrm{CFI} \quad=1,000$

TLI $\quad=1,016$

NFI $\quad=1,000$

RFI $\quad=0,999$

RMSEA $\quad=0,000$

\section{Multivariate Outlier}

Uji multivariate outlier dideteksi berdasarkan nilai Mahalanobis Distance (MD) dari setiap nomor observasi. Uji multivariate outlier menggunakan ChiSquare : $\mathrm{X}^{2}(6 ; 0,001)$, diperoleh sebesar 22,458

1) Bila MD $(\boldsymbol{n}) \geq 22,458$ diindikasikan nomor observasi ke $\boldsymbol{n}$ mengandung outlier.

2) Bila MD $(\boldsymbol{n})<22,458$ diindikasikan nomor observasi ke $\boldsymbol{n}$ tidak mengandung outlier.

Apabila data hasil penelitian ditemukan outlier pada observasi maka hal tersebut akan di eliminier. Tujuan mengelimenier yang mengandung outlier untuk mendapatakan model struktural terbaik dari 147 observasi. Berdasarkan hasil analisis, semua data observasi terbebas dari asumsi Multivariate Outlier sebanyak 98. Dengan demikian data observasi yang terbebas dari outlier di analisis menjadi 98.

Hasil Koefisien dan probabilitas Model Persamaan Struktural Tabel 4.5 Regression Weights

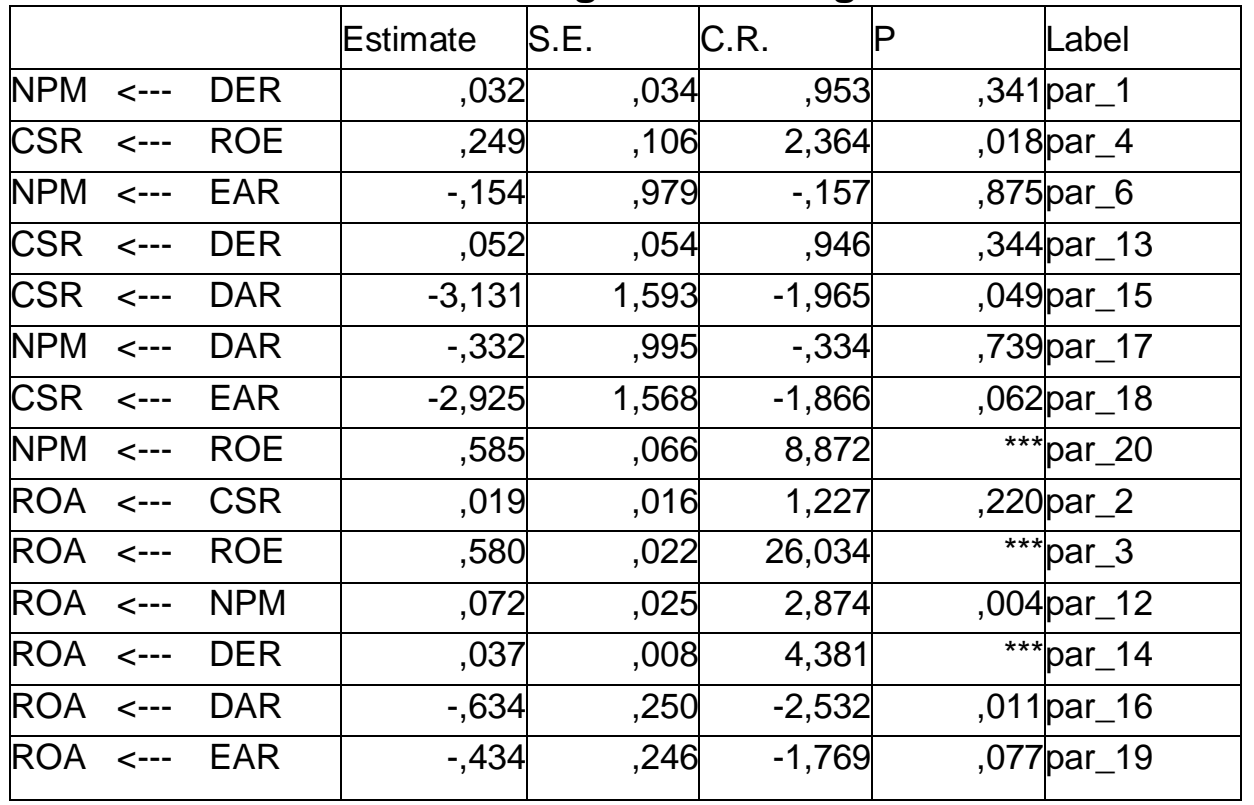


Berdasakan output tersebut diperoleh nilai signifikasi $(p)<0,05$ $(5 \%)$ sebayak 7 model hal ini mengindikasikan bahwa masing-masing variabel mampu dijelaskan oleh variabel yang bersangkutan secara statistik.

Berdasarkan output regresi weight mengindikasikan bahwa pengaruh dari ROE, DAR, DER dan EAR terhadap ROA melalui NPM hanya ROE lah yang berpengaruh terhdapa ROA melalui NPM sedangkan variabel yang lain tidak berpengaruh.

Berdasarkan output regresi weight mengindikasikan bahwa pengaruh dari ROE, DAR, DER dan EAR terhadap ROA melalui CSR menyatakan bahwa dari hasil output ini menunjukan bahwa tidak terdapat satupun variabel yang berpengaruh terhadap ROA melalui CSR.

\subsection{Hasil Kooefisien Standartdized Pengaruh Langsung, Pengaruh Tidak Langsung Dan Total Pengaruh}

Tabel 4.9 tabel kooefisien Standartdized Pengaruh langsung, pengaruh tidak langsung dan total pengaruh

\begin{tabular}{|l|r|r|r|}
\hline & $\begin{array}{c}\text { Pengaruh } \\
\text { Langsung }\end{array}$ & $\begin{array}{c}\text { Pengaruh Tidak } \\
\text { Langsung }\end{array}$ & $\begin{array}{c}\text { Total } \\
\text { Pengaruh }\end{array}$ \\
\hline ROE terhadap NPM & 0,674 & 0 & 0,674 \\
\hline ROE terhadap CSR & 0,243 & 0 & 0,243 \\
\hline ROE terhadap ROA & 0,858 & 0,069 & 0,927 \\
\hline DAR terhadap NPM & $-0,584$ & 0 & $-0,584$ \\
\hline DAR terhadap CSR & $-4,657$ & 0 & $-4,657$ \\
\hline DAR terhadap ROA & $-1,431$ & $-0,190$ & $-1,621$ \\
\hline DER terhadap NPM & 0,212 & 0 & 0,212 \\
\hline DER terhadap CSR & 0,284 & 0 & 0,284 \\
\hline DER terhadap ROA & 0,311 & 0,028 & 0,338 \\
\hline EAR terhadap NPM & $-0,273$ & 0 & $-0,273$ \\
\hline EAR terhadap CSR & $-4,384$ & 0 & $-4,384$ \\
\hline EAR terhadap ROA & $-0,989$ & 0,153 & $-1,142$ \\
\hline NPM terhadap ROA & 0,092 & 0 & 0,092 \\
\hline CSR terhadap ROA & 0,029 & 0,029 \\
\hline
\end{tabular}




\section{Penilaian Goodness of Fit Model}

Hasil estimasi menghasilkan model yang fit sebagaimana ditunjukkan oleh berbagai Goodness of Fit-stat Model, antara lain CMIN:

Tabel 4.10 Goodness of Fit Model

\begin{tabular}{|l|c|c|c|}
\hline \multicolumn{1}{|c|}{$\begin{array}{c}\text { Goodness of Fit } \\
\text { (GOF) Index }\end{array}$} & $\begin{array}{c}\text { Cut-off } \\
\text { Value }\end{array}$ & $\begin{array}{c}\text { Nilai pada } \\
\text { Model }\end{array}$ & Keterangan \\
\hline $\mathrm{p}$ (probabilitas) & $>0,05$ & 0,769 & Good fit \\
\hline RMSEA & $<0,08$ & 0,000 & Good fit \\
\hline GFI & $>0,90$ & 1,000 & Good fit \\
\hline CFI & $>0,95$ & 1,000 & Good fit \\
\hline TLI & $>0,90$ & 1,016 & Good fit \\
\hline NFI & $>0,09$ & 1,000 & Good fit \\
\hline RFI & $>0,90$ & 0,999 & Good fit \\
\hline
\end{tabular}

Dari hasil analisis dapat dilihat bahwa model secara keseluruhan memperlihatkan tingkat kesesuaian yang baik. Dengan demikian dapat bahwa hasil pengujian goodness of fit pada model yang dipakai dalam penelitian ini menunjukkan bahwa data yang diobservasi sudah sesuai atau konsisten dengan teori.

\section{SIMPULAN DAN SARAN}

Kesimpulan yang dapat diambil dari penelitian ini adalah

1. $R O E, D A R, D E R$ berpengaruh secara langsung terhadap $R O A$. Sedangkan $E A R$ secara langsung tidak berpengaruh terhadap $R O A$.

2. ROE secara langsung berpengaruh terhadap NPM. Sedangkan $D A R$, $D E R$ dan EAR secara langsung tidak berpengaruh terhadap NPM.

3. ROE dan DAR secara langsung berpengaruh terhadap $C S R$, sedangkan $D E R$ dan $E A R$ secara langsung tidak berpengaruh terhadap CSR.

4. NPM berpengaruh secara langsung terhadap ROA. Sedangkan CSR secara langsung tidak berpengaruh terhadap $R O A$.

\section{DAFTAR PUSTAKA}

Aprianto, Rully. 2016. Pengaruh Corporate Social Responsibility Terhadap Kinerja Keuangan (ROE) Dengan Manajemen Laba dan Ukuran Perusahaan sebagai Variabel Moderating (Studi Empiris Pada Perusahaan Pertambangan Yang Terdaftar di BEI periode 20112014). JOM Fekon vol. 3 no 1.

Beny,B. 2012. Coorporate Social Responsibility. San Fransisco

Binangkit, A Bagas. 2014. Pengaruh Struktur Modal Terhadap Kinerja Perusahaan dan Harga Saham Pada Perusahaan Manufaktur di Bursa Efek Indonesia. Jurnal aktual edisi. Vol.1. No.2.

Brigham, E. F dan Houston, 2006. Dasar-dasar Manajemen Keuangan, Edisi Sepuluh, Penerbit Salemba Empat, Jilid I, Jakarta. 
Ghozali, Imam. 2011. Aplikasi Analisis Multivariat Dengan Program IBM SPSS 19. Edisi 5. Cetakan V. penerbit: Universitas Diponegoro. Semarang.

Ghozali, Imam. 2004. Model persamaan struktural konsep dan apliksi dengan program amos 24. Edisi 7. penerbit: Universitas Diponegoro. Semarang.

Hadi, N. 2011. Coerporate Social Responsibility. Penerbit Garaha IImu. Yogyakarta.

Ikhwal, Nuzul. 2016. Analisis roa dan roe terhadap profitabilitas Bank Di Bursa Efek Indonesia. Jurnal LK dan Perbankan Vol. 1 nomor 2.

Rahman, Reza. 2009. Corporate Social Responsibility. MedPress. Yogyakarta.

Sari, Warsani Purnama. 2016. Pengaruh Struktur Modal Terhadap Aktivitas Operasi Pada Perusahaan Yang Terdaftar Di Bursa Efek Indonesia. Jurnal Ekonomi, Keuangan dan Kebijakan Publik (JEKKP).

Suja'l, A Yusuf Imam. 2012. Aplikasi Program Amos Untuk Analisis Pemodelan Struktural. Edisi 2. BPFE Unisma.

Sutrisno. 2001. Manajemen Keuangan Teori, Konsep dan Aplikasi, Edisi Pertama Ekonosia, Yogyakarta.

Syari, Dina Waroh Kartika. 2014. Pengaruh Likuiditas Dan Leverage Terhadap Kinerja Keuangan Perusahaan Rokok Di Bursa Efek Indonesia. Jurnal IImu dan Riset, vol. 3 no 3. 